\title{
The Extrinsic Elements of Harper Lee's to Kill a Mockingbird
}

\author{
I Nyoman Djuana ${ }^{1}$, I Gede Angga Kusuma Jaya ${ }^{2}$ \\ Faculty of Letters, Universitas Warmadewa Denpasar-Bali, Indonesia ${ }^{1,2}$ \\ \{nyoman.djuana@gmail.com¹, angga.kusuma@gmail.com²\}
}

\begin{abstract}
This study aims to find out the extrinsic elements and its influences found in the novel story To Kill A Mockingbird by Harper Lee. This study used the method of library research, which is the data is described qualitatively. Furthermore, the theory used is Wellek \& Warren's theory The Theory of Literature (1956). Based on the analysis, it was found that there are four extrinsic elements in the story, there are (1) Biography of the author which indirectly influenced the story. It can be seen in the similarity of Atticus Finch and Amasa Coleman first career experience, Dill Harris has similarity family problem with Truman Capote, and they both have the same intelligence. (2) Social elements can be divided into two aspects: Personality the author viewed from her environment, and culture aspect, and the culture aspect is the fact that the culture around the author also inspires the author to incorporate it into the story. (3) Psychological of the author is the fact that psychic conditions such as the habits or behaviour of the author also influence the author to include one of the characters in the story. (4) Historical aspect is the fact that the history of American racism inspired the author and incorporated it into the story, thus making the story interesting. It can be said that racism is one of the important factors in this story.
\end{abstract}

Keywords: Literature; Extrinsic Elements; Novel

\section{Introduction}

A work of fiction is a part of literature or one of the branches of art. Literature has existed in human civilization for thousands of years ago. Its existence in human civilization cannot be denied. In human civilization, it has been accepted as one of social-cultural realities and is not just regarded as an artwork that uses language as its medium. In its reality in the human development, writing really life of mirrors, and life is in measure of colossal, a reality of social, notwithstanding the way which basic world and internal or passionate universe of person have in like manner been objects of abstract impersonation.

The author's point of making his work is to improve his expertise and capacity in portraying the thoughts or the truth of the environment. The literary work delivered by the writer can reflect moral mentalities of specific individuals or different things identified with individuals' life. The literary works which additionally mirror these things are novels, for example Harper Lee's To Kill a Mockingbird [1]. As is in drama and poetry, novel likewise portrays life which 
happens in the public eye. It is likewise an image of reality and habits of time in which is written. Its story additionally has a structure that is essentially developed by two literary components there are intrinsic and extrinsic components. Extrinsic elements are characterized as the literary elements/factors which can be found external the artistic works yet in a roundabout way impact the structure of the literary works. The extrinsic approach is utilized by critics to underscore the significance of setting and psychology too. The story in question has also extrinsic components. Its extrinsic components, however, not fully understood. For this reason, this study attempts to analyze and to find out the extrinsic elements and its influences found in the novel.

Some latest related studies conducted by the researchers, one of them is studied by [2] reveals that the elements of this story utilizes conventional story, the portrayal of the significant character as an independent woman, this story utilizes first person perspective on the grounds that the storyteller is the character in this story, and the theme of this story is about love. Moreover, in research carried out by [3] showed that plot, characters, setting of time and place, and point of view from Victoria's was the intrinsic elements of Mama film. The elements of extrinsic had effects on detailing topic of Mama film. A research [4] showed that the intrinsic elements can't be isolated each other on the grounds that plot, theme, character and characterization, point of view and setting are the solidarity that constructed a novel from inside. Thus, based on the background and latest related studies above, it can be asserted that there are two kinds of elements in story, they are intrinsic and extrinsic. The latest related studies are different from the present study, and it can be assumed that the present study is never be done since this present study is going to find out the extrinsic elements and its influences found in that novel. Therefore, the objective of this study is to find out the extrinsic elements and its influences found in the novel story To Kill A Mockingbird by Harper Lee. This study is expected give more understanding about the extrinsic component of this novel.

\section{Method}

This study applied library research, which is the data are described qualitatively based on a theoretical basis. The data source is taken from a novel entitled To Kill a Mockingbird by Harper Lee. The novel is chosen since this novel could be found history, socio, and psycho incident of author biography. Data are collected and analyzed by reading the novel, finding out the statements that belong to extrinsic aspect, and then they are classified in accordance with the problem discussed.

\section{Results and Discussion}

This study aims to find out the extrinsic elements and its influences found in the novel story To Kill A Mockingbird by Harper Lee. As a result of the analysis, it was found that there are four aspects of extrinsic found in that novel. Those are author biography aspect, social elements, psychological aspects, and historical aspect. The further analysis of the extrinsic elements in that novel is shown as follows. 


\subsection{Biography of the Author which Indirectly Influenced the Story}

Word of biography is derived from the Greek words bios which means life, and graphos which means write, is a record of life of a person, ordinarily conveyed as a book or paper, or in some other structure, for instance, a film. An account is more than an overview of reality of generic, it moreover describes the story of subject, highlighting the diverse piece of their life, including comfortable experiences nuances, and join an assessment of the subject of character.

To Kill a Mockingbird novel has an account of life of a person which indirectly affects the formation of the story in the novel. The life story of the author has relevance to the story she made. The first linkage author's life with the story narrated in the author's biography has relevance in the story is about her father first career experience, Truman Capote (her closest childhood friends) who is based as Dill Harris and the beginning of a friendship with Michael Martin Browns. Biography of the Author which indirectly influences the story can be seen in the paragraph below:

When my father was admitted to the bar, he returned to Maycomb and began his practice. Maycomb, some twenty miles east of Finch's Landing, was the county seat of Maycomb County. Atticus's office in the courthouse contained little more than a hat rack, a spittoon, a checkerboard and unsullied code of Alabama. His first two clients were the last two persons hanged in the Maycomb county jail. Atticus had urged them to accept the state's generosity in allowing them to plead guilty to second-degree murder and escape with their lives, but they were Haverfords, in Maycomb County a name synonymous with jackass (Lee, 1960).

The narrator of this story is Scout, the daughter of Atticus, so the paragraph above was Scout's point of view. In the paragraph above, the narrator told us the profession of Atticus Finch and by reading that sentences, we may know that Atticus' office is in the town hall and it's contained minimal in excess of rack of a cap, a spittoon, a checkerboard and unblemished code of Alabama, and his initial two customers were the last two people hanged in the Maycomb County prison.

The things above are showing the similarity of the first career experience between Harper Lee's father and Atticus in the story of To Kill a Mockingbird novel. It was known that Harper Lee's father named Amasa Coleman Lee has a first career experience similarity with Atticus finch that proved in the Harper Lee biographies which stated "in 1915 he breezed through the Alabama bar exam and started to specialize in legal matters, primarily in Monroe County. Before her dad turned into a title lawyer, her dad once guarded two individual of color blamed for killing a white vendor. The two customers, a child and father were hanged". That statement has a similarity with To Kill a Mockingbird quotation above, that's mean Amasa Coleman is an inspiration for Harper Lee's to make Atticus Finch character in To Kill a Mockingbird novel.

\subsection{Social Aspects which influenced The Story}

Literature is a social organization, utilizing as its medium language, a social creation, for example, customary abstract gadgets as imagery and simple are social in their very nature. They are shows and standards which might have emerged distinctly in the public eye. Since its birth, the social sciences have no exact boundaries or definitions of the subject matter. That is, in contrast to the exact sciences whose formulation is certain, the formula in social science is uncertain because its emphasis on dynamic human behaviour, always changing over time. 


\section{a) The personality of the Author Viewed from her Environment}

The advancement of character is impacted by four commonly strong variables, in particular: first, natural heredity. Actually there is no individual who has similar actual attributes, in spite of the fact that he was conceived twins however. Hence, the natural highlights of every individual are one of a kind character. Actual character and nature are near biogenetic components. The indigenous habitat is the place where public activity is extremely assorted, for example, atmosphere inconstancy, common assets, and geographic area, and, the social legacy. Among culture and nature has a corresponding relationship, implying that nature influences human character. There are some personalities of the author through main character, viewed from her environment, it can be seen in the sentence below:

Being southerners, it was a source of shame to some members of the family that we had no recorded ancestors on either side of the battle of Hastings. All we had was Simon Finch, a furtrapping apothecary from Cornwall whose piety was exceeded only by his stinginess. (Lee, 1960:03)

From the paragraph above, it was known that Scout is a southerner and part of South America, the southern people have character is often known as a friendly or is referred to as the southern hospitality phrase that shows that the southern people is friendly, sweet, and welcomes anyone to come visit their house, this hospitality is identified as a part of the Southern people's values and norms known as highly religious people, which is something that Christians should do, but for some her family's member being southerners is not always good more precisely it was a source of shame, that's because their family was not has anything to proud except Simon Finch whose piety was exceeded only by his stinginess. As we know that in social science, natural environment has an important role to make a personality. As well as Harper Lee she was born in Monroeville, Alabama and that's mean Scout environment inspired by Harper Lee's small-town Monroeville, Monroe County, Alabama and it also proves that Harper Lee and Scout are both growing in similar areas and similar natural environment. That's making Scout be a helpful person because life in South America surrounded by friendly people, that's proving by this sentence:

I turned around and saw most of the town people and the entire delegation looking at me... I rose graciously on Walter's behalf (Lee, 1960:14).

\section{b) Cultural Aspect which Influenced The Story}

Culture contain models, unequivocal and comprehended, of and for direct picked up and sent by pictures, setting up the specific achievements of human social events, recalling their embodiment for relics: the fundamental focus of culture includes traditional (for instance really decided and picked) considerations and especially their associated characteristics: culture structure may, from one viewpoint, be considered as aftereffects of action, on the other, as prohibitive parts of future movement. There are some cultural aspects in the real world which appears or influenced the story. It can be seen in the sentence below:

Jem was football crazy. Atticus was never too tired to play keep-away, but when Jem wanted to tackle him Atticus would say, "I'm too old for that, son." (Lee 1960: 99)

In the sentence above, it can be seen that Jem, Atticus' son, a character in To Kill a Mockingbird novel, was a football crazy. In the real life, football is a very popular sport and many people especially boys love it very much. In this story, Jem is a boy he was football crazy, the author could be inspired by the boys in the real life and it influenced her novel. Another cultural aspect which influenced the story could be seen below: 
Jem reopened Ivanhoe and began reading. I tried to keep up with him, but he read too fast. When Jem came to a word he didn't know, he skipped it, but Mrs. Dubose would catch him and make him spell it out. (Lee 1960: 118)

Based on the paragraph above, it can be seen that Jem reads a book entitled Ivanhoe. In the real world, Ivanhoe is a historical novel by Sir Walter Scott, first published in 1820 in three volumes. The novel is a part of literature, and literature is a part of the culture. Perhaps the novel Ivanhoe influenced Harper Lee, so she put it in To Kill a Mockingbird story.

\section{c) Psychological of the Author}

By 'writing brain research' inferring that the psychological examination of the writer, as type and as an individual, or the examination of imaginative cycle, or the examination of the psychological sorts and laws present inside works of composing, or finally the effects of composing upon its perusers (swarm cerebrum science). Questionable positively is the far and wide view that neuroticism and 'remuneration' separate craftsman from researcher and other pondering. The undeniable qualification is that authors regularly record their own cases, transforming their diseases into their topical material. There are some psychological of the author that indirectly influenced the story. One of them can be seen in the following paragraph.

In high school, Lee developed an interest in English literature. After graduating in 1944, she went to the all-female Huntingdon College in Montgomery. Lee stood apart from the other students she couldn't have cared less about fashion, makeup or dating.

(Harper Lee's Biography)

From the paragraph above, we know that Harper Lee is grown up as a tomboy and cared less about fashion. A spitfire is a young lady who shows qualities, including wearing manly attire and participating in games and exercises, that are physical in nature and are considered in numerous societies to be unfeminine or the space of young men. That's mean Harper Lee's characteristic is indirectly influenced the character of her main character in To Kill a Mockingbird novel, in her novel story Scout or real name Jean Louise Finch, which has some similarities with Harper Lee.

\section{d) Racism (Historical Aspect)}

History is the investigation of past functions, especially in human undertakings. History is the investigation of the past as it is depicted in composed reports. There are some moments in this fiction which are related to the historical events in the real world, it can be seen in the following paragraph:

But I was worrying another bone. "Do all lawyers defend n-Negroes, Atticus?" "Of course they do, Scout." "Then why did Cecil say you defended niggers? He made it sound like you were runnin' a still." Atticus sighed. "I'm simply defending a Negro-his name's Tom Robinson. He lives in that little settlement beyond the town dump. He's a member of Calpurnia's church, and Cal knows his family well. She says they're clean-living folks. (Lee 1960:83)

The paragraph above shows us the dialog between Scout and her father, Atticus, after Scout get mocked by her friend in the school because her father defends a Negro. It was happened because in this novel, white townspeople hated the Negroes, even if actually they are innocent. The paragraph below also shows us about the hatred of the Whites to the Negroes: 
"Yes indeed, what has this world come to when a Finch goes against his raising I'll tell you!'" She put her hand to her mouth. When she drew it away, it trailed a long silver thread of saliva. "Your father's no better than the niggers and trash he works for!" (Lee 1960:113)

The paragraph above shows us the situation when Mrs. Dubose met Jem and Scout, and Mrs. Dubose affronts them by saying that their dad isn't superior to the niggers and the rubbish he works for. It shows us that the Whites hates the Negroes very much, and a white person who defends a Negro will also be hated.

\section{Conclusion}

Based on the analysis above, it can be concluded that there are some extrinsic elements which could be found in Harper Lee's To Kill a Mockingbird. There is the biography of the author, social aspects, cultural aspects, psychological of the author and historical aspect. There is some biographical aspect of the author which influenced the story, for instance, the similarity between Scout, the main character in the story and Harper Lee, the author of the story. Both of their father was a lawyer. Two man who was defended by Lee's father was hanged, so does Atticus' client. Another biographical aspect is Harper Lee's childhood friend named Truman Capote inspired her to make a character named Dill in this story, and Dill's personality is same as Truman Capote's. There are some social aspects which influenced the story, for example, natural environment, social heritage, and family circumstances can make a temporary or permanent change of personality to the author as well as Scout one of the main character. There is some cultural aspect in the real world which influenced the story, for example, in America, football is a famous sport. The setting of this story is also in America, and Jem, one of the character, is a football crazy. Another cultural aspect which influenced this story is Halloween. Halloween is a very popular celebration in America, and Harper Lee adds it to this story. In this novel, the people in Maycomb County also celebrated Halloween. The psychological aspect of the author also influenced this story. In the real world, Harper Lee is a tomboy girl, and Scout, the main character of this story is also has a tomboy personality. There is also some historical aspect which influenced the story. The history contained in this novel mostly related to racism. In the real life, there was racism in America to some races especially Negroes. Racism in the United States has been widespread since the colonial era. There are some moments in this story which shows us the racism, for example, when Jem and Scout get mocked and get insults from people around them. In the real world, The Jim Crow laws which existed between 1876 and 1965 made the Negroes and the whites have separated facilities. The Negroes were given separated public facilities like buses, trains, school, etc, and they weren't allowed to use White's public facilities. In this story, the Negroes have separated church from the Whites. The Negroes can't go to pray or worship in the Whites' church, they must use their own church, similar like in the real world.

\section{References}

[1] H. Lee, To Kill a Mockingbird. London: Arrow Books, 1960.

[2] D. P. Ardiyanthi, "The Intrinsic Elements of The House by Dina Oktaviani," State Islamic University "Syarif Hidayatullah” Jakarta, 2010.

[3] D. Indriani, S. Sili, and S. Ariani, "An Analysis of Intrinsic Elements in Mama Film by Andreas Muschietti,” Jurnal Ilmu Budaya, vol. 3, no. 1, pp. 13-24, 2011. 
[4] E. Kusumawati, "An Analysis on Intrinsic Elements of Agatha Christie's 'The Pale Horse," State Islamic University "Syarif Hidayatullah” Jakarta, 2007. 